\title{
Sadhana Naithani, Folklore Theory in Postwar Germany, University Press of Mississippi, Jackson, 2014, 142 p.
}

\author{
Ioana Repciuc* \\ "A. Philippide" Institute of Romanian Philology, Str. Th. Codrescu 2, 700481 Iași, Romania
}

This book by Sadhana Naithani, an associate professor at the Jawaharlal Nehru University in New Delhi, offers an outside perspective, both figuratively and literally, on the foundation of European folklore studies. The present research takes into account traditional folkloristics, i.e. that centred on language analysis and folklore text, which stayed close to the basis of the disciplines established by the Brothers Grimm as early as the $19^{\text {th }}$ century.

A native of the cultural space considered by classical folkloristics as the cradle of universal folktales, the author has distinguished herself recently by critically overcoming the old boundaries between centre and periphery in researching the Indian folktales, as well as between the folklore theories established on the two continents in the last century ${ }^{1}$. Indeed, her professional career exemplifies the transgressing of the respective cultural antagonisms by her specialization in the language, culture, and German folklore.

The aim of this book is to reevaluate the first decades after World War II, which was a boundary moment in the history of folklore research in postNazi Germany. Though the same topic stirred up strong debates starting with the '60s and continuing until recently (Bendix, 1997, p. 157-158; Gingrich, 2005, p. 138-148), the New Delhi researcher brings about an additional evaluative view. The reason for this assessment seems to be the desire of stimulating a reconsideration of philological folkloristics, frequently accused of being unable to synchronize with new directions encouraged by the western ethnological sciences through their evolution towards anthropological and sociological methodology.

The introduction, polemically entitled "Does Folklore Matter?" delineates some answers given to frequent challenges to folkloristics' validity as a science of a reality that threatens to disappear. The motivations for its survival in a particular situation is the topic of this book.

The first part is dedicated to explaining the cultural context at the origin of Volkskunde in the $19^{\text {th }}$ c. German culture - i.e. Grimm Brothers' endeavor to collect and publish folktales. Volkskunde emerges and develops itself in a close connection with the German philology - Germanistik. Even though there were expectations in this respect, Jakob Grimm was not successful in taking over the first chair of Germanistics at the University of Berlin, which would have highly influenced the discipline's orientation from classical philology to "wilde Philologie" - the research into spoken language's dynamics. Therefore the "science of the people" will become a separate philological discipline in the years to come, though it had a steady effect toward encouraging the choice of texts researched by Germanistics.

This heritage shared by both Volkskunde and Germanistik heavily influenced folkloristics' subsequent trajectory as it evolved towards a text analysis, a statistical science and archive-based research. Additionally, both disciplines were developed under the rise of Romantic nationalism initiated by Herder and amplified further by the cultural activism of Grimm Brothers. Folkloristics' nationalist orientation as a science encouraging the emergence of European nation-states evolved in Germany's case towards the well known extreme consequences of Nazism, while the cultural propaganda of the Third Reich heavily interfered with the ethnological research (Dostal, 1994; Hauschild, 1995). The author describes the tension felt in the 1950s when a thorough list of accusations was filed against folkloristics, which almost ruined this discipline.

Though Volkskunde survived in the 1960s during intense discussions at the yearly conferences of

\footnotetext{
*Email address: repciuc_i_o@yahoo.com.

${ }^{1}$ See her recent book in this domain (Naithani, 2010).
} 
Deutsche Gesellschaft für Volkskunde, the discipline became divided into two directions with different interests, called by Sadhana Naithani "the path of discontinuity" and "the path of transformation" (p. 26). Those choosing the definitive separation from the past, led by Hermann Bausinger ${ }^{2}$ at Tübingen University, evolved towards a social-anthropological perspective, and was known as "Europäische Ethnologie" (Kaschuba, 1999, p. 78-96), especially in the scholarly circles of northern and central Europe. The main topic of this orientation was no longer the folklore text, but the present time's social dynamics, the daily life holistically researched. Therefore Volkskunde becomes Empirische Kulturforschung. Under the influence of American folkloristics' contemporary changes and the domestic debate stirred up by the Frankfurt School, the new German ethnology would go further away from the traditional topic of folk text analysis, getting as far as pointing at the philological and historical excesses of the ethnological sciences (Bausinger \& Brückner, 1969).

The second direction discussed here is the school of folkloristics at the "Albert Ludwigs" University in Freiburg, created by Lutz Röhrich (1922-2006), who was supporting the continuation of traditional research. Naithani underlines that Röhrich was continually aware of the necessity to eliminate the ideological aspects of ethnological research imposed between 1933-1945. Nevertheless, he reacted differently from his Tübingen colleagues by choosing a gradual depoliticization through a detailed critique of the past as opposed to a fast separation from it. As the author explains, his work cannot be described as failure to evolve, but actually as an effort to take notice of complex contemporary matters (p. 28). Refusing any political aspect of folkloristics is effected, as Naithani shows, by consciously avoiding any strong theoretical claim and therefore any dangers this could bring. Absence of theoretical speculations in Röhrich's analytical system made him vulnerable to accusations of unproductive descriptivism, especially because folkloristics generally had been repeatedly considered as such.

In the central section, the author closely follows Röhrich's professional itinerary, proving how well she knows his work and owing this to the fact he has been her doctoral thesis coordinator a thesis entitled Politik der Liebe, written between 1990 and 1994. In the first chapter of this section, the New Delhi folklorist traces Röhrich's folktale research design, and in the next one she comments how the German scholar interpreted this folklore text's relationship with different interpretations that it received over time. The last chapter describes the professor's work in the field of another important subject of traditional folkloristics - the Volkslied.

Founder and mentor of Freiburger Schule, Röhrich will stay faithful to the so-called philological folkloristics which he has adapted in his own way, and identified a personal manner of preserving the model which proved efficient due to the lasting tradition of folklore text research in the German lands. The postwar imperative of breaking with the past has called into question the German folkloristics' broad projects: Atlas der deutschen Volkskunde and Enzyklopädie des Märchens ${ }^{3}$. A group of folklore scholars decided to continue traditional work in lexicography, cartography and archive-based research of folklore. One of the few surviving projects was Deutschen Volksliedarchivs ${ }^{4}$, founded by John Meier in 1914. In 1953, the archive is saved from disintegration and transferred to Freiburg where it would be directed by Lutz Röhrich until the end of his career.

Though Naithani does not integrate Röhrich's research interests within the extensive context of folk text analysis consecrated by the historicalgeographical and comparative school that originated in Finnish folkloristics, the Freiburg professor's relation with this prestigious research tradition is highly relevant. Analyzing Röhrich's professional path we can also grasp the complex challenges that all European folkloristics had to face in a changing academic world in which text was more and more in danger of being abandoned for the sake of a greater emphasis on the performative context.

Faithful to the old school, Röhrich chooses as his main topic those folk texts which were central for prewar scholars, starting with Herder and the Grimm Brothers: the folktale and the folk song.

\footnotetext{
${ }^{2}$ With his book consecrated in the history of German ethnology as a polemic manifest encouraging the definitive transition from the nationalist canon to the social study and fieldwork (Bausinger, 1961).

${ }^{3}$ At which Röhrich has contributed with articles since 1973 and until the end of his life.

${ }^{4}$ Today this archive is a separate institution within Zentrum für Populäre Kultur und Musik at Freiburg University.
} 
His main work published a decade after the war, in 1956, deals with the controversial relation between folktale and reality: Märchen und Wirklichkeit. Eine volkskundliche Untersuchung (Röhrich, 1956). The book could be read as a sort of answer to the new ethnologists and postwar critiques who were not able to see in the folktales anything other than reified bits of language lacking relevance for the comprehension of contemporary German society. Trying to prove the opposite, Röhrich becomes a contemporary "advocate of the folktale" (p. 30), as the title of his last book suggests (Röhrich, 2002a).

Sadhana Naithani shows in detail how her former professor argued his particular position, how he managed to avoid rigidly placing folktales in a certain spatial and temporal reality as the Nazis did, and to understand the folktale in a fantasy frame. On the contrary, for the German scholar the folktale reflects universal traits of human existence beyond ethnic and historical boundaries (p. 56-58), within a perspective approached today by the textual anthropology promoted by Michael Metzeltin. Though it was a topic made sensitive by the recent political events in his country, Röhrich takes into account one of the main reasons for the German academic world's reluctance to study folktales in the traditional way - the fact that this type of approach transformed the folk text into a source of inspiration for the Nazis' cruelty. The Third Reich cultural designers' symbolic manipulation of power relations schematically displayed in folktales is probably the darkest and strangest page of text analysis in the history of humanities.

The German folklorist was not able to totally ignore this problem, so he connected it with the complex nature of the so-called "interpretation circles" (p. 61) that included alternatively scholars, folklore collectors, anthropologists, politicians, cultural activists, common readers. The different evaluations of folktale reality, which are the outcome of subjective lectures and of the process of "rationalization" (p. 65) proposed by these contributors to the text's hermeneutic destiny, cannot be stopped or censored because the folktale is, as any other written and published text placed at the disposal of its readers, "a cultural object" (p. 62) and also a historical one (p. 113). Transforming this object into a political one is an unwanted consequence of this unobstructed freedom of interpretation.

Another way by which Naithani believes that Röhrich tried to transform the old philological method shared by both Germanistics and folkloristics was to explicitly avoid analyzing the folklore texts as part of the German ethnic imaginary (p. 79). This is a valid solution as the epic themes of folktales move freely beyond national borders - a fact demonstrated minutely by the Finnish school of international folktale typology.

As for the folk song research, the author shows the main aspects of the analysis proposed by Röhrich, underlining the fact that he was interested in revealing the social and historical context in which the song was performed and transmitted, in identifying and commenting all the versions of a particular type spread in time and geographically, in the social and cultural features of performers (Röhrich, 2002b). Naithani calls this type of approach "history from below" (p. 113) - a text analysis directed towards a quasi-exhaustive reflection on all the text levels starting with the formal variations and finishing with its dissemination within the social milieu.

Finally, in the last section of the book, the Indian researcher places Röhrich's work within international folkloristics and especially within European and North American folk narrative research. The New Delhi scholar explains Röhrich's contribution to South-Asian folkloristics that is actually her own main field in which she has conducted research on narrative creativity of contemporary Indians.

The merit of Freiburg folkloristics would be, as Naithani concludes, not to have reacted against any change whatsoever, but to have accepted it on its own terms. Instead of utterly abandoning the literary and philological folkloristics' valuable tradition, which was basically developed by the German postwar branch of the discipline, Röhrich chose to critically recycle the past in connection with identifying new, more balanced strategies of linking the documents in archives and typologies with the presenttime social reality.

Röhrich's work and, implicitly, the favorable presentation of it by Naithani could easily be defined as one unproductive and biased exercise in support of an extinct era. But today, in a transitional time of different ethnologies in open conflict with both

\footnotetext{
${ }^{5}$ The "Odyssey" reference was used by the renowned Danish ethnologist Bjarne Stoklund to describe the intricate position of his
} 
Scylla and Charybdis ${ }^{5}$, the decision to avoid extreme versions exhibited by the two opposing sides becomes a brave one. Sadhana Naithani's approach could be also read as an example for other national folkloristics that passively defer to the prestige of their own tradition, encouraging them to start a self-imposed exercise of distancing themselves from this unchallenged self-contained authority. The Indian researcher concluded that her German mentor has passed this complex examination of critical reconsideration, but it is possible that many other highly respected theoretical systems of the discipline, quietly accepted until now, are not so successful.

\section{References}

Bausinger, H. (1961). Volkskultur in der technischen Welt, W. Kohlhammer Verlag, Stuttgart.

Bausinger, H. \& Brückner, W. (eds) (1969). Kontinuität: Geschichtlichkeit und Dauer als volkskundliches Problem, Schmidt, Berlin.

Bendix, R. (1997). Departures and Revisions. Toward a Volkskunde without Canon, in In Search of Authenticity. The Formation of Folklore Studies, The University of Wisconsin Press, Madison / London, p. 159-187.

Dostal, W. (1994). Silence in the darkness: German Ethnology during the Nationalist Socialist Period, in "Social Anthropology", vol. 2, no. 3, p. 251-262, CrossRef.

Gingrich, A. (2005). The German-speaking countries, in One Discipline, Four Ways: British, German, French, and American Anthropology, The Halle Lectures, with a Foreward by Chris Hann, University of Chicago Press, Chicago / London, p. 45-156.

Hauschild, T. (1995). Lebenslust und Fremdenfurcht - Ethnologie im Dritten Reich, Suhrkamp Verlag, Berlin.

Kaschuba, W. (1999). Einführung in die Europäische Ethnologie, C.H. Beck, München.

Mellemgaard, S. (2014). Rupture and Continuity. Reflections between Synchrony and Diachrony in Ethnology. In Memoriam Bjarne Stoklund, in "Ethnologia Europaea". Journal of European Ethnology, vol. 44, no. 2, Museum Tusculanum Press, University of Copenhagen, Copenhagen, p. 94-110.

Naithani, S. (2010). The Story-Time of the British Empire. Theory of Transnational Folkloristics, University Press of Mississippi, Jackson.

Röhrich, L. (1956). Märchen und Wirklichkeit. Eine volkskundliche Untersuchung. 5. Aufl. Baltmannsweiler, Schneider-Verlag, 2001. Habilitationsschrift, Universität Mainz.

Röhrich, L. (2002a). „und weil sie nicht gestorben sind...”. Anthropologie, Kulturgeschichte und Deutung von Märchen, Böhlau Verlag, Köln.

Röhrich, L. (2002b). Gesammelte Schriften zur Volkslied-und Volksballadenforschung, Waxmann Verlag, München.

discipline between the diachronic approach and the synchronic one as similar to crossing the Messina strait where it is menaced by both Scylla-absorption into the traditional vision and the past, and Charybdis - the definitive integration into those social sciences benefiting from a closer connection with present realities up until the loss of the discipline's autonomy (apud Mellemgaard, 2014, p. 97). 